\title{
USING DRAMA TECHNIQUES AS A COMMUNICATIVE APPROACH IN TEACHING ENGLISH AS A FOREIGN LANGUAGE TO FOREIGN LEARNERS IN THE CLASSROOM OF SECONDARY SCHOOLS
}

\author{
SANAA' SA'EED MiRZA \\ Dept. Of English, College Of Languages, University Of Duhok, Kurdistan Region-Iraq
}

(Received: July 8, 2019; Accepted for Publication: November 18, 2019)

\begin{abstract}
Unfortunately, many of our students graduate from secondary schools with no English at a satisfying level, except a few simple phrases with lowering of self-esteem and confidence. These problems come from teachers' little awareness that the aim of teaching English as a foreign language is shifted from grammatical teaching to communicative teaching, and this shift requires the use of modern methods of teaching involving the drama techniques to achieve this aim. The current theoretical research aims at highlighting the role of the drama techniques approach in teaching English integrating it with their traditional approaches of teaching.

This study hypothesizes that teaching English through drama techniques approach can help teachers achieve better results, vitalize the classroom, motivate both teachers and students, and have more fun. The significance of this study is to inform the present and the future teachers of the secondary schools the benefits of the integration of drama techniques with other methods in the classroom.

The current study is divided into five sections. Section one presents an introduction to the drama, its definition and how its techniques have been used in the field of education. Section two presents the literature review about the using of drama techniques in teaching English. Section three presents a brief study of the general concept of the Communicative Approach and its activities. Section four concentrates on the definition of drama techniques approach, its techniques and importance in teaching English. This section also presents some advices to teachers in introducing drama techniques, preparing for a play, and the actual performance. Section five presents a conclusion that using drama techniques in the classroom improve students' speech, communication and presentation skills, build their confidence, develop their critical thinking, engage them in a creative problem- solving and decision, develop their physical and emotional skills and encourage teamwork and co-operation. Finally, this research ends with a list of references in addition to Arabic and Kurdish synopsis.
\end{abstract}

KEY WORDS: Grammatical teaching, Drama Techniques, Communicative Approach, Co-operation

\section{I.INTRODUCTION}

A Ulas (2008, p.877) has stated "although drama has existed as a potential language teaching tool for hundreds of years, it has only been in the last thirty years or so that its applicability as a language learning technique to improve oral skills has come to the forefront", using drama techniques as a method in language teaching is not new, it has dated back to the 1970s. But this method has recently been used significantly after it has proved its amazing effectiveness in stimulating students' skills in primary and secondary schools to teach English. Many studies have confirmed that drama techniques method has many advantages can be taken from if it has integrated with other traditional methods (Ashton-Hay, 2005).

Drama as a genre of literature is regarded as the mother of all arts, it is used to perform, educate, and entertain. It comes from the Greek meaning "to act, do or perform". Its root is found in ancient Greece and Rome. Drama is defined as "a composition designed for performance in the theatre, in which actors take the roles of the characters, perform the indicated action and utter the written dialogue" (Abrams, 1999, p.69). It is also defined by Dryden as "A play is a just and lively image of human nature, representing its passions and hum-ours and the changes of 
fortune to which it is subject for the delight and instruction of mankind". (Mambrol, 2017, p.36).

For many years, drama has remained confined within the theater's walls, until Susan Holden has come to define it as "any kind of activity where learners are asked either to portray themselves or to portray someone else in an imaginary situation", to bring out the drama from the walls of the theater to the sphere of education (Holden, 1981, p.2). Thus, drama becomes "concerned with the world of 'let's pretend"' that provides student with opportunities "to express himself through verbal expressions and gestures using his imagination and memory" (Holden, 1981, p. 6).

\section{LITERATURE REVIEW}

The basic idea of using drama techniques in education came with no doubt from the late teachers' perception of the idea that young children preferred to integrate learning with play. This perception later expanded to include the students of primary and secondary schools.

Nevertheless, most teachers, in primary and secondary schools scoffed at the idea of using drama techniques in teaching language, because they still envisioned drama in education as in a theater, required students' memorizing dialogue, acquiring props, costumes, and painting sets. But this view was changed after the scholars distinguish drama in education from drama in the theater, in addition to the pleasant findings of many survey studies that were done to determine the effectiveness of using drama techniques as a method in teaching language comparing with mechanical repetition (Via, 1985).

Therefore, the scholars in many countries began firstly to differentiate between the dramatist who wrote plays and the teacher of drama who taught the principles of drama, secondly between drama in theatre and drama in education. Drama in theater as many literary scholars defined, referred to the performance of a script by actors on a stage before audiences, and this collaborative work required author, composer, producer, and director of the play. While drama in education as Maley and Duff (1982) asserted, referred rather to all activities that reflected students' personality, ideas, imagination, and feelings. Maley and Duff believed that "these activities draw on the natural ability of every person to imitate, mimic and express himself or herself through gesture" (1982, p. 6).

Although the scholars used different terms for the drama in education, such as; educational drama, creative drama, developmental drama, mantle of the expert, informal drama, and process drama, they all agreed that the main aim of it was developmental and educational. It practically, motivated students to perform a story they read before or an original plot in an improvisational way, to understand and synthesize any context without translation, and to use their own words and imagination without resorting to memorization. Maley and Duff (1982) asserted that all words would be turned to ashes in the student's mouth if they memorized mechanically, therefore Maley and Duff supported the idea of using drama techniques or activities in teaching language to stimulate students' imagination and memory to express themselves and their past experiences by using their own words in English. So in educational drama, teacher did not need to force his students to memorize words, paint sets, or prepare costumes and props, since no script, technical aides, or audience were used (Coney\& Kanel, 1997:8)

In 1981, Holden highlighted the role of drama techniques in foster students' socialization, problem-solving, oral communication skills, critical thinking, and increasing their self-confidence to speak English fluently. She believed that drama techniques improved students' language skills, group cooperation, and their personal and sensory awareness that boosted their imaginative growth and encouraged their creativity. In 1983, Rivers stated that "drama approach enables learners to use what they are learning with pragmatic intent, something that is most difficult to learn through explanation" (p.21). Rivers believed that drama techniques could provide students with an opportunity to use language in more meaningful situations and that is what other traditional methods could not do. Rivers also approved the using of drama techniques to break the humdrum and the boredom of a conventional English class encouraging the students to take a more role and responsibility in the process of learning. $\mathrm{He}$ confirmed that drama techniques enabled the teacher as well as the students to transform the syllabus into one that prepares students to speak English fluently without fear or shyness and to 
face their world with self-confidence (Rivers, 1983).

In 1984, Hayes came to agree with Rivers' opinion that drama techniques motivated teacher to transform the syllabus from the book into a practical application and this process would stimulate students to participate and to acquire language skills (Hayes, 1984).

In 1987, Dougill came to assert that "theatre" (the performance of a play on a stage) and "informal drama" (a series of activities that related to drama techniques) should not be seen separately, since both had the same meaning: "the imitation of an action", as Aristotle defined, and both could be used in a language class (Dougill, 1987, p.1). Dougill believed that the integration of the theater with the informal drama could help student to be more confident in his use of the target language since it would allow him to experience the language in a meaningful situation $(1987$, p. 7).

In 1990, Larsen-Freeman assured that drama techniques, as a method, based on the Communicative Approach. The main goal of it focused on how to make the students communicate and speak the language fluently. It employed the language within a meaningful situation and social context. Therefore, the communication would be meaningful and significant, as it is "socio linguistically appropriate". Then, the teacher had to correct students' error afterwards without interrupting their normal flow of communication. In such approach, the role of the teacher would be transformed from one of the information provider to a guider and a facilitator of learning, and the lesson would be changed from teachercentered to student- centered (Larsen-Freeman, 1990).

In 1998, Kao and O'Neill made a study and noted that drama techniques approach developed student's linguistic and social skills through improvised and immediacy activities that involved students actively in the teaching process. Kao and O'Neill noted that drama techniques approach offered opportunities for students to use a meaningful and purposeful language as an authentic and essential tool of communication fluently. Meaningful context played a major role in developing students' capacity to engage in complex and creative communication through their listening, understanding and imaginative responding. It also enlivened and illuminated student's perceptions and strengthened their willingness to work constructively and seriously (Kao and $\mathrm{O}^{\prime}$ Neill, 1998).

In 2002, Burke and O'Sullivan appeared to sum up the reasons for using drama techniques approach in teaching English as a second language in several points:

1. Drama techniques approach gave teacher and his students an opportunity to focus on language semantically and syntactically

2. It stimulated both teacher and his students to bridge a gap between the classroom and real life situations by providing insights into how to handle tricky situations.

3. Drama techniques approach encouraged students to overcome the problems of fear and shyness and to feel relax

4. Drama techniques approach motivated teacher and his students to use language for meaningful purpose.

5. Drama techniques approach stimulated the students to learn many physical skills

6 . It encouraged students to cooperate and work in a team.

7. Drama techniques approach developed students' abilities and skills, such as selfconfidence, critical thinking, communication, and initiative

8. Drama techniques approach gave teacher and his student an opportunity to discuss sensitive topics

In 2003, S. Phillips came to confirm the truthiness of the famous Chinese proverb "tell me and I will forget; teach me and I will remember; involve me and I will learn", when he summed up the aim of drama techniques approach into transforming the "theoretical knowledge" to "practical or experienced knowledge" (2003, p. 5-6). Phillips asserted that drama techniques approach melted practically, the personality of "shy student" into another character in the story, and this personalization could encourage him to be active in his participation. This process of personalization might stimulate student's imaginative power to play the role of the character that he/ she wanted to be in the future, overcoming his/ her problem of shyness (Phillips, 2003).

In 2006, Fleming's study on drama and mime came to demonstrate that drama techniques approach gave students an opportunity to express their thoughts, emotions and feelings, 
which might vary depending on the communicative situation since semantically, each sentence could give different meanings according to when, where and how it had been used and pronounced.

In 2009, one study, conducted by Desiatova assessed the effects of using drama techniques in creating a vibrant, familiar and enjoyable environment for both students and teachers. Desiatova revealed that students could understand and learn new English vocabulary words through drama techniques by using their previous knowledge in a creative way, interpreting the meaning of words from a context without using a dictionary, interacting with each other and working with imagination and fantasy. In his study, Desiatova used the techniques of storytelling and role play to show the impact of these two techniques on students to acquire English language vocabulary. The result of this study was in favor of both techniques to acquire vocabulary successfully (2009).

In 2010, a study carried out by Demircioglu who observed 50 students between the ages of 9 and 10 found a significant difference between the marks of the experimental group that followed drama techniques in teaching English and the second group that followed the traditional approach (giving equivalents of the words or showing the pictures), without practicing any drama activities, and this difference was in favor of the experimental group (2010, p. 441-42).

In the same year, Gomez and his colleagues, in a public school in Madrid, made a survey study about the effectiveness of the use of drama techniques in English teaching as opposed to traditional methods. After three weeks, the students had examined pre and post-instruction. Gomez and his colleagues found out after they collected and analyzed the data that teaching English through drama techniques was much better than using traditional methods (2010).

Moreover, Koyluoglu made a survey study at the University of Selchuk, about the effect of drama techniques in teaching grammar. Koyluoglu chose 17 students randomly from Kadınhanı Ata İçil High School. She divided them into two groups, experimental and control. Both groups studied the same topic, but with a different methods. The experimental group studied the simple present tense by using drama techniques, while the other group studied it by using the traditional method. The result of the test and observation proved the effectiveness of drama techniques in teaching grammar (2010).

In 2014, Žero who made a survey about the impact of drama techniques on preschool children found out many benefits of using drama techniques in an EFL classroom.

1-For Žero, drama techniques approach strengthened students' ability to memorize and remember because it depended on "learning by doing".

2- It improved their capacity for communicative competence and fluency.

3 -It could be used in language teaching of any age. (2014: 12).

In 2015, Sofi-Karim asserted in his research English Language Teaching in the Kurdistan Region of Iraq that the Kurdistan Regional Government started to use the Sunrise program published by Macmillan, for students of primary and secondary schools in 2007. Sunrise provided students with a valuable resource of selfexpression, creativity, and language. It taught English through enjoyable approach by using drama techniques such as; role playing, storytelling, telephone conversation, and team work. On the other hand, Hassan and Ghafor revealed in their survey study which was made to evaluate the suitability of Sunrise program for Kurdish learners in Irbil city, that most of teachers and students were satisfied with this program because it presented various activities and exercises (Hassan and Ghafor, 2014).

In 2016, a survey study was made at the Foreign Languages Department of South Ural State University about the role of drama techniques in teaching English as a foreign language and revealed that the stimulation of students to learn was increased by $63 \%$, the opportunity to explore the potential of creative students was by $54 \%$, the opportunity for selfexpression was by $38 \%$, the ability to work in a team was by $42 \%$, and the developing intercultural competence was by $68 \%$. According to these results, the scholars who made the survey study concluded that drama techniques could be considered as a means of acquiring linguistic and non-linguistic skills valuable in the professional field of a student's life. Drama techniques could be used to improve student's linguistic competences, such as; his vocabulary, grammar, pronunciation, social communication as well as his self-confidence, 
skill of presentation, teamwork skills. Therefore, drama techniques should not be used merely for fun but as a student- centered approach to improve student's linguistic as well as physical skills (Shraibe and Yaroslavova, 2016: p.64).

In 2017, many academic studies proved that the effectiveness of drama techniques in education was certainly not limited to the language teaching and learning, but to the acquisition of knowledge in general. For example, Soleymani and his colleagues concluded that drama techniques; such storytelling and creative drama had a great impact to improve children's awareness about their personal hygiene. The result of their study showed that storytelling and creative drama were appropriate methods not only in the area of health education, but also in the social and psychological educations for teenagers and adults (Soleymani and etal, 2017).

In 2018, Masoumi-Moghaddam made a survey study about using drama and drama techniques to teach English Conversations. $\mathrm{He}$ chose 30 undergraduate male and female students from public secondary and high Schools in Ardebil. He divided them into two groups, experimental and control. Both groups were given a Test-Retest assessment to measure the targeted language skills.

The experimental group taught English conversation through drama techniques approach and two dramatic discourse that were used on Arthur Miller's 'The Death of a Salesman' and Henrik Ibsen's 'A Doll's House', while the other group taught it through traditional method. The result of the test and observation proved the effectiveness of drama techniques in teaching English conversation.

Furthermore, much recent brain research demonstrated how the arts were able to facilitate the process of teaching/learning English, to improve their linguistic and intellectual skills as well as their social interaction. According to the individual differences, each student learned best a little differently. Some learned best by visual, some by audio and some by movement. However, the creative teacher was able to activate and stimulate student's senses by using activities that combined all three types of learning. This is why teachers should integrate many methods and use various activities in the classroom involving drama techniques approach, since it is a flexible approach and could be integrated with all other methods of teaching (Moore, 2004, p. 15).

Although there is a continuous development in the curricula of teaching English language and methods of teaching,

\section{COMMUNICATIVE APPROACH}

Communicative approach is an approach that emphasizes the interaction in teaching foreign language as both means and goal. It aims not only at learning the grammatical structures and rules of the language but also at communicating the language in a meaningful situations. Communicative approach refers more to communicate the language than to learn the grammatical and lexical aspects, but that does not mean to neglect them. It summarizes the process of teaching/ learning language in two question words "What" and "How". The word "what" refers to the content that students should learn. It emphasizes the ability to use the language accurately and fluently in a meaningful situation for communication meaning rather than to memorize the grammatical rules, forms, and structures. The word "how" refers to the different activities and techniques that should be used to learn language through communication. Drama Techniques approach provides many activities and techniques for interesting and productive practice which attract learners' attention to communicative techniques, tasks, and activities, suitable for all levels to teach language in the classroom. Drama Techniques approach is an appropriate approach to teach any foreign language fluently and accurately (Richards, 1985).

\section{III.I COMMUNICATIVE ACTIVITES}

'Communicative activities' are all activities and techniques that used in communicative method to teach foreign language. The term refers to the games, practices, exercises, presentation, and projects which are used in the classroom to do things with language e.g. playing role, telling story, evaluating, comparing and bridging the information gap, making choices. It is used for communication and interaction. Communicative activities are purposeful and interactive, they improve students' skills of reading, writing, speaking, and listening. Drama techniques approach can be used in the classroom as a communicative approach since its techniques foster 
communication among students and provide them with opportunities to use the target language in different meaningful situations (Richards and Rodgers, 1986). "Advocates of the Communicative Language Teaching (CLT) approach" declare that drama techniques "are extremely popular in teaching English as a second language (TESL)", "because of their holistic effect on the personality development". Drama techniques "are widely used in roleplays, simulation and language games which cause physical and emotional activity, foster imagination and improvisation" ( Shraiber\& Yaroslavova, 2016: 60).

\section{DRAMA TECHNIQUES: DEFINITION AND IMPORTANCE}

Drama techniques approach is defined as "a combination of procedures that organize learner's role-related behavior in specially designed game situations promoting to develop both communicative competence and student's personality as a whole" (Shraiber\& Yaroslavova, 2016: 60). The term 'techniques' refers to the various activities which are practiced in the classroom. Fleming asserts that drama techniques are all activities that "widely used in role-plays, simulation and language games which cause physical and emotional activity, foster imagination and improvisation" (Fleming M., 2013). Dramatic techniques are defined as "the everyday tools of the drama teacher. They help to develop enquiry skills, to encourage negotiation, understanding and creativity. They can enhance performance skills such as character development and storytelling and be used across the curriculum to involve students actively in the process of learning" (Farmer, 2011, p.5).

IV.I THE IMPORTANCE OF DRAMA TECHNIQUES IN ENGLISH LANGUAGE TEACHING

Drama techniques approach has an important impact on English language teaching. It can be considered as an ideal approach in teaching language. It is the most effective way that provides students with opportunities to learn English in the context of everyday situations with the emphasis on communicational skills. Drama techniques approach allows students to speak through a context that is relevant to their life and need. It stimulates them to use meaningful language in a meaningful situation to reveal their artistic talents and creative potential. Students become more active and motivated to learn a number of vocabulary and use it in different situations, and this reinforces their learning. In respect to the language skills, drama techniques improve students' skills of speaking and listening. When a student plays a role, he has to listen very carefully to his pairs' speech to be able to react as the situation requires. So, these two activities are interrelated. To improve students' skills of listening and speaking, teacher can stimulate students to listen and practice many exercises such as; small talks, telephone calls, cartoons, songs, directions, announcements, and many more. In all these exercises, teacher can easily use drama techniques to improve students' fluency, intonation, and pronunciation. On the other hand, teacher can stimulate his students to read and write a poetry, a short story, a short scene, an advertisement, a song and a letter, correcting their mistakes to improve their skills of reading and writing. These activities stimulate students to use their imagination and creative potential. (Elena, 2016).

Besides, drama techniques develop student's social skills through taking part in a drama. When students play a role in a play they try to interact and strive to understand each other. Such activity helps them to overcome linguistic and social problems. Moreover, drama techniques approach stimulates students to be more tolerant and empathetic with each other and to work in a team sharing the responsibility. In addition, drama techniques can eliminate boredom and monotony in the classroom through various activities that make the process of learning more lively and enjoyable. The drama techniques approach creates an atmosphere to overcome two problems spontaneously; the fear of using the English language in front of others and the fear of making mistakes. It helps students to gain the confidence and self-esteem to express themselves in real situations without fear and shyness. Thus, the drama techniques approach develops students' linguistic and social skills through communicative activities that are, unfortunately, neglected in the conventional method of teaching English which hardly gives students an opportunity to use language in such a manner. What truly important in using the drama techniques approach is that it empowers students 
to take more role and responsibility in the process of learning English. It changes the process of teaching and learning from teachercentred to student-centred (Culham, 2003).

To emphasize the importance of drama techniques in language teaching, Kao and O'Neill mention in their book, "Words into Worlds" that "[D]rama does things with words. It introduces language as an essential and authentic method of communication. Drama sustains interactions between students with the target language, creating a world of social roles and relations in which the learner is an active participant. Drama focuses on the negotiation of meaning (1998). The language that arises is fluent, purposeful and generative because it is embedded in context. By helping to build the drama context, they develop their social and linguistic competence as well as listening and speaking skills." (Kao and O’Neill ,1998: 4).

Furthermore, to understand the role of drama techniques in education, individual differences must be taken into consideration. Some students learn quickly by using visual tools, some prefer the audible, and others by kinesthetic, but the best way of learning is to combine all of these types. This is why teachers must be creative to integrate the drama techniques with all methods of teaching connecting the new information with student's past experiences and his everyday life to create something new in their minds. Lawson states in his book, Brain-Based Learning that "[E]ach brain is unique. Genetic and environmental factors influence learning and the connections between cells are created by an individual's unique experiences" (Lawson, 2001, p.1).

Drama techniques approach presents opportunities for students to explore the curriculum and be fully involved in the teaching/ learning process by their minds, senses, emotions, and bodies. Therefore, the teacher who uses drama techniques in teaching is adopting the "whole-brain" method, since student's whole brain is stimulating. As a result, the student's absorption of the subject will be better. Dickinson says that "[T]hey (the arts) provide rich multisensory experiences that engage the whole mind-body-emotional system" (2002: p.1). "Facts and information become relevant when they are relevant to the lives of the people the students imagine" (Edmiston, 1998: p. 4).
Teaching/ learning process requires student's attention which is activated by the brain, yet as Dr. Perry states "neural systems fatigue quickly, actually within minutes. With three to five minutes of sustained activity, neurons become 'less responsive'; they need a rest (not unlike your muscles when you lift weights)" (Perry, 2004: p. 1). So, after few minutes, student's attention will be distracted to look for other internal or external stimuli if the teacher does not stimulate his students "to do something with information they learn, and then they can process information more deeply. Students need to use what they have learned to reinforce it" (Feden, 2003: p. 1). Drama techniques approach helps students to learn without losing their attention and without forgetting the information.

\section{IV.II DARMA TECHNIQUES AND ACTIVITIES}

Drama techniques are simple, available, and cost-effective tools used to achieve various goals of education. The drama techniques combine elements of storytelling, role-play, improvisation simulation and games to play similar roles in language teaching. They can be considered as a bridge "between the classroom and the real world" (Holden, 1981:89). These techniques and activities also introduce a variety of methods to make the process of teaching/learning language more effective, lively and interesting. They enhance and develop the essential skills needed for literacy improvement, academic success, and social communication. Drama techniques are creative and varied and to choose the optimal one, there are several components that teacher must take into consideration. These components are: the subject matter and its aims, the resources available at the school, the individual differences among students - the required skills. Samples of these techniques are:

\section{IV.II.I ROLE PLAY}

Role play, as Livingstone states is "a classroom activity which gives the student the opportunity to practice the language, the aspects of role behavior, and the actual roles he may need outside the classroom" (1985: p. 6). It is an important technique in which student personalizes or reincarnates another character in the text. The teacher must pay attention to several things, as before he chooses the context and assign the roles to the students. The teacher must keep in mind his student's levels, their competence in English language, needs, 
individual differences, age, previous experiences and interests. Afterwards, each student is given what is suitable for him/her. The teacher provides students with precise role descriptions and information about each character such as; their names, age, physical and psychological characteristics so that students can play their roles accurately. Role play gives students opportunity to use the English language without their teacher's manipulation. Then, students can evaluate and express their opinion about their roles and the performance in general (Dougill, 1987). Role Play as Blatner asserts help students become more effective, involved and interested by applying knowledge to work, by solving problems and evaluating alternatives. Role Play helps students enhance their English language, develop their abilities and skills, such as selfconfidence, critical thinking, teamwork, communication, and initiative (2002).So, in order to be successful, the teacher should choose the techniques that make students "active almost $100 \%$ of the time" (Livingstone, 1985, p. 25). During the performance, the role of teacher should be, as Livingstone indicates, "as unobtrusive as possible" (1985, p. 31). He asserts that the "task of the teacher is to improve performance in the foreign language, not alter personality. Roles, then, can be created to fit not only the linguistic ability, but also the personality of the individual student" (Livingstone, 1985, p. 28). So, in Role Play teacher may either sits outside the performing space, plays a minor role, or moves round the students. On other hand, Livingstone asserts two main disadvantages with practicing this technique, the first one is with insufficient size of the classroom, and the second one is with the time that role play takes up since it takes the whole lesson (Livingstone, 1985, p.28). Wagner who is an internationally recognized authority on composition instruction and the educational uses of drama indicates that the "role playing is improvisational, not scripted and memorized to present a performance for an audience. The emphasis is on drama as an intentional teaching strategy to enhance learning in a particular curricular area" (Wagner, 1998: p.5). It can be to any subject matter, "it is particularly effective in making a historical event come alive for students" (Wagner, 1998: p.5). In a study made by Moore to show the effectiveness of the technique role play in teaching Thanksgiving ritual instead of talking about it. He concluded that all students liked this technique and intensely involved to teach about Thanksgiving ritual (Mayflower, Pilgrims, Native Americans, feast), dressing to perform their roles. Many of them presented extra research about how Pilgrim would look and act like (Moore, 2004: p.10). Furthermore, this technique can be used to read and summarize a story, play, novel, or any reading material. It helps students can be used to understand the writing rather than to follow the story. A teacher can give 1 minute to his students to present a summary of what they read. Then, teacher can help his students to choose crucial moments in the story to be acted within two to four minutes.

\section{IV.II.II TELEPHON CONVERSATIONS}

This technique enables the students to listen carefully, understand quickly, and react fluently. Although the student is free to say whatever he likes, he has to sustain a meaningful telephone conversation according to what his pair says. This technique enhances students' skills of speaking-listening. To apply this technique, a teacher should divide the class into groups of 2 students. Each pair should sit with their backs to each other, so they can only hear their voice. Each student imagines that he/ she is a different character. A teacher may depend on a text borrowed from their book to build up a telephone conversation or ask students to discuss a topic or solve a problem to build up a dialogue. A teacher may ask each pair to write down the conversations to be exchanged and read by other pairs (Chauhan, 2004).

\section{IV.II.III QUASTIONING IN ROLE OR HOT SEATING}

It is another technique of drama used to teach the students how to speak fluently, answer his colleague's questions objectively, take notes, and write down a report. It enables the student to read, comprehend, interpret, perform the role of the main character in the story, and then answer questions about it. After performing the role of character in the story, the teacher asks the student to sit on a chair in front of a semi-circle group to answer their questions about the character. If the character is familiar to the students, then it is not necessary to perform the role of character in front of the students. The teacher tells the group of the students that they are newspaper reporters at a press conference to 
make an interview with the character after his/her performance or adventure. The newspaper reporters work in teams to write down their own notes about the character and his/her adventure to prepare their reports report. After the end of the interview, the student who has been questioned can join one of the teams of the reporters. The reports will be read and discussed to choose the best one to be hanged on the wall, and which student gives the best interview to write the article or report (Chauhan, 2004).

\section{IV.II.IV OPEN AND CLOSE}

In this techniques, still images, flickering films, or series of photographs are used to tell a story. Teacher may divide the class into two or more groups. Each group show 3-5 still images to the other students to tell a story. Teacher or one student from each group is responsible for telling the other students to close or open their eyes when the groups rotate their position.

When the designated student says "Close", all student should close their eyes a few moments until the first group prepare their first image. Students open their eyes and look at the image after the designated student says "Open". The process of (Open and Close) is repeated until all the groups show their still images and tell the whole story (Farmer, 2010).

\section{IV.II.V SOLILOQUY / THOUGHT TRACKING}

This technique enhances student's skills of reading, writing, comprehending and interpreting. The teacher divides the class into groups of five or six students. The students of each group find out the crucial point of time in the life of the main character in the story to talk about it. Sometimes, the teacher gives the crucial point of time to all groups of the students to be discussed. The crucial point can be a time of loss, isolation, struggle, disappointment, success, or a time of monologue. After selecting a crucial point of time, the students of each group articulate and interpret aloud the character's thoughts and point of view to each other. Then, each group has to work on a final interpretation of the character to be presented in front of the class by one student who performs the personality of the character and goes through that crucial moment. After the performance, the class discusses which selection and performance are the best. Thought tracking enables students to express verbally their understanding of the characters and situations. It also helps the students to be confident and speak aloud in front of others without fear or shyness. (Farmer, 2010).

\section{IV.II.VI FLY ON THE WALL}

This technique requires the student's imaginations. A Teacher motivates his students to imagine a fictitious scene in a cave, a village, a deserted island, a castle, or a monastery. The students work individually to imagine the place as if they were a fly on the wall. A teacher may ask them some questions to identify their senses and sharpen their imaginations; for example, what they can see, what they smell, how they feel, and so on. A teacher may use appropriate music to create the atmosphere. Then, a teacher can divide the class into groups of 2 or more students to write down their reports about the imaginative scene (Farmer, 2010).

\section{IV.II.VII WORD TENNIS}

In this technique, two students or two teams of two students stand in front of the class, thinking up words of the same chosen category and stick them to each other as a ball of tennis. The student who repeats an earlier or can't think of a new one loses the game and is replaced by another one. The categories that student choose include animals, capital cities, colours, birds, fruit, characters of fairy tale, sea creatures, adjectives, adverbs, flavours of juice or ice cream, , sports, adverbs, and so on. Students can change the categories to maintain interest (Farmer, 2010).

\section{IV.II.VIII STORYTELLING}

Storytelling is one of the simplest and most creative technique. It encourages students to use their imagination to create a story. A teacher may tell a story and then encourage his students to share him their stories one by another. To make the lesson more attractive and enjoyable, a teacher may show his students videos of storytelling or invite a professional storyteller to tell a story and teach them some techniques they can use in their own stories, such as the words, sound effects, intonation facial expressions, physical gestures, mime, rhythm, repetition, rhythm, details, exaggeration, and the interaction with the audience. (Farmer, 2010).

\section{IV.II.IX MIME}

Mime is defined as "a non-verbal representation of an idea or story through 
gesture, bodily movement and expression"(Dougill, 1987: p.13). It emphasizes the performance of students through gesture, dance, and facial expression without speaking. It helps students to overcome their fear and shyness by encouraging them to perform their roles in front of other students. It builds up students' confidence and develops their imagination. Mime helps students "to be very enthusiastic about this aspect of drama", (Hayes, 1984), since it is enjoyable and not concerned with language. After the performance, the teacher asks his students to narrate or interpret what the performer does on the stage (Hayes, 1984).

\section{IV.II.X A WARM-UP}

This technique can be used to tell the teacher a lot about his students, and also to make the class more vital and enjoyable. A teacher may divide the class into two groups. Each member of the group has to mime a name of a film, a title of a book, a phrase, or a proverb, to his own group without mouthing any word, and his group should guess it within 3-5 minutes. These names should be in English and familiar for the students to guess them. They also should be easy for the volunteer to mime them. The volunteer has a right only to use gestures, for example, his fingers to show the number of the words in the title. A teacher has to teach his students common gestures to be used for articles and prepositions before the beginning of the activity. The role of a teacher lies in his controlling and managing the activity. If the group guesses the title correctly within the limited time, it will win a point (Farmer, 2010).

\section{IV.II.XI ROLE ON THE WALL}

It is a technique used to find out more information or characteristics about a character, theme or object. Teacher asks his students to draw an outline of a body on a large sheet of paper and hang it onto the wall. Then, the students may describe the character physically and psychologically or add opinions, motivation, occupation, achievements, dreams, secrets, location, or subjective ideas in a form of words or phrases onto the drawing or write down them on a sheet of paper and hang it with the drawing on the wall. This drama technique can be used as an individual or a group activity. The students can return back to the drawing to add or change the information. TO be more effective, this technique can be used with other techniques such as; Hot Seating (Farmer, 2010).

\section{IV.II.XII CONSCIENCE ALLEY}

Conscience Alley technique or Thought Tunnel can be used to study a story, discuss a theme or describe a historical event. It is used to explore any kind of decision, problem, or dilemma faced by a character in the story. To use this technique, the teacher should read aloud the story and explains the problem or the dilemma that the character faces in the story. The teacher may choose any student to take the part of the character in the story. Then the teacher divides the class into two groups to present their own advices, one side for and the other side against. When the student who walks between the two lines, listening to their opposing advices reaches the end of the tunnel, he has to take his decision by himself to dissolve the problem, or dilemma. Then, the teacher discusses with his students, whether the taken decision is correct or not. The Conscience Alley technique is used to teach the students how to face their own problems, listen to the opposing advices, and then, take the correct decision to solve them (Farmer, 2010).

\section{IV.III TEACHER ROLE}

In using drama techniques, the role of the teacher will be shifted from merely the source of knowledge or information provider to a guide, adviser, and a facilitator of learning. As Hoetker states that "the teacher who too often imposes his authority or who conceives of drama as a kind of inductive method for arriving at preordained correct answer, will certainly vitiate the developmental values of drama and possibly its educational value as well." (1969, p: 10). So, when teacher instigates and empowers his students to take more responsibility and to do more activities for their own learning, the class will be changed to student-centered rather than teacher-centered. In that, Barnes says "Education should strive not for the acceptance of one voice, but for an active exploration of many voices"(1968, p:10). When the process of teaching is changed to student-centered, there will also be a significant shift in emphasis from what is taught to what the students learn.

\section{IV.IV SOME ADVICES TO TEACHERS IN INTRODUCING DRAMA TECHNIQUES}

1-The teacher should have a clear aim in mind, when he introduces the activity. 
2-The teacher should share the purpose with his students, by explaining it to them before each activity

3-The teacher has to be sure that all students understand what they have to do, and then let them use their own words, personality and experiences to play the role of characters of the activity.

4- The teacher should share his students the performance of the activity to reduce their stress and clarify any ambiguity about the activity (Maley and Duff, 1985, p. 22).

5-The teacher should not intervene if there are silent moments or something goes wrong.

6-The teacher should encourage his students to speak fluently, to listen accurately, to think critically to each other's ideas.

7-The teacher should give a feedback on the whole process, what the students have done, their achievement, their collaboration in groups and their finding of a decision.

8-After any activity, the teacher should give his opinion, concentrating on the positive points to motivate the students and reinforce their work.

9-The teacher should not interrupt the activity to correct or discuss the mistakes of the students.

10- The teacher has to keep in mind that his students are not professional actors, but they are just using their English in an enjoyable way (Phillips, 2003).

11-To correct the mistakes of the students, the teacher should use "hot cards" by writing down his notes about their mistakes and discussing them with the students or writing down examples of correct usage of language.

12- The teacher should create a pleasant and friendly atmosphere.

13-The teacher should give his students enough time to think and to practice the activity.

14-The teacher should not force anyone of his students to practice the activities especially, if he is lacking confidence.

15-The teacher should provide his students with appropriate materials, such as pictures, photocopies, objects, etc (Dougill, 1987, p. 133).

\section{CONCLUSION}

The current study that relies in its content on survey studies about the role of drama techniques in teaching English, concludes that the approach of drama techniques has a positive effectiveness in teaching English as a foreign language. It can be used as a stand-alone method and can also be integrated and adapted with other tradition methods to add vitality and activity in teaching English.

Drama techniques approach is an engaging teaching strategy that develops collaboration, cooperation, self-esteem, goal-oriented learning and language skill. It bridges the gap between the text and natural usage, and can also help to bridge a similar gap between the classroom and real life situations by providing insights into how to handle tricky situations.

The drama techniques approach has a great effectiveness in teaching all subjects areas besides language. It gives the teacher the opportunity to be creative and competent in teaching English. It involves the students in the learning, motivates them to practice engaging activities, develops their critical thinking skills to overcome difficult situations and solve problems, embraces their emotions, and stimulate their creativity and imagination which are ignorant in traditional methods. The cognitive, emotional, and affective skills that are acquired through drama techniques method may create intelligent, motivated, lifelong students.

\section{REFERENCE}

Abrams, M. H., \& Harpham, G. G. (1999). A Glossary of Literary Terms. Boston, Mass: Thomson Wadsworth.

Ashton-Hay, S. (2005). Drama: Engaging all Learning Styles. Proceedings 9th International INGED (Turkish English Educational Association) Conference. Economics and Technical University in Ankara, Turkey. Retrieved on November $11^{\text {th }}$, 2018, from http://eprints.qut.edu.au/12261/1/12261a.pdf

Barnes, Douglas (1968). Drama in the English Classroom. Champaign, illinios: national Council of Teachers of English

Blatner, A. (2002). Role Playing in Education. Retrieved on May 13th, 2018 from http://www.blatner.com/adam/pdntbk/rlplayed u.htm

Burke, A. \& O'Sullivan, J. (2002). "Stage by Stage: A Handbook for Using Drama in the Second Language Classroom": Retrieved on May 13th, 2018 from http://www.heinemann.com.

Chauhan, V. (2004). Drama Techniques for Teaching English. The Internet TESL Journal. Vol. X, No. 10, (3). Retrieved on May 13th, 2018 from http://iteslj.org/Techniques/ChauhanDrama.html 
Coney, R. \& Kanel S., (1997) Opening the World of Literature to Children through Interactive Drama Experiences. The Association for Childhood Education International Annual Conference

Culham, Cameron. R. (2003). "Making the conversations possible: Drama as a methodology in developing the language of the everyday in ESL classrooms". University of Victoria.

Demircioglu, S.(2010). Teaching English Vocabulary to young learners via drama. Faculty of Education, Gazi University, Ankara, Turkey. Retrieved on July 4th, 2018 from: www.sciencedirect.com

Desiatova, L. (2009). Using Different Forms of Drama in the EFL Classroom. Humanising Language Teaching Magazine, issue 4. Retrieved on May 13th, 2018 from http://www.hltmag.co.uk/aug09/sart07.htm

Dickinson, Dee.(2002). "Learning Through the Arts." New Horizons for Learning. Seattle: New Horizons for Learning.

Dougill, J. (1987). Drama Activities for Language Learning. Macmillan Publishers Ltd. London.

Edmiston, Brian, and Jeffrey D. Wilhelm (1998). Imagining To Learn: Inquiry, Ethics, and Integration Through Drama. Portsmouth, NH: Heinemann.

Farmer, David (2010). What Are Drama strategies? Retrieved on May 17th, 2018 from http://dramaresource.com/strategies>

Farmer, David (2011). Learning Through Drama in the Primary Years. Published by Lulu, Illustrations (C) David Hurtado

Feden, Preston, and Robert Vogel, (2003). "How the Human Brain Learns is the Basis for New Teaching." Retrieved on May 17th, 2018 from

<http://www.lasalle.edu/univcomm/2003/cogn itive.htm $>$

Fleming, M. (2006). Drama and language teaching: the relevance of Wittgenstein's concept of language games. Humanising Language Teaching Magazine, issue 4. Retrieved on May 17th, 2018 from http://www.hltmag.co.uk/jul06/mart01.htm

Fleming M. (2013). "Drama" in Byram. M. (ed.) Encyclopedia of Language Teaching and Learning. London, Nitra.

Gomez, David Izquierdo (2010). "Using drama to improve oral skills in the ESL classroom". International Schools JournalVol XXX No.1 November 2010.

Hassan, Fatimah Rashid and Omar Fouad Ghafor (2014). Assessing the Suitable of "Sunrise" Programme to the Kurdish Learners of the Seventh Basic Grade in the Schools of Erbil
City. Journal of Teaching and Education, University of Halabja, Iraq.

Hayes, Suanne, Karbowska, (1984) Drama as a second language: A practical Handbook for language teachers. National Extension College.

Hoetker, James (1969). Dramatics and the teaching of literature. Champaign, Illinios: National Council of Teachers of English. ERIC clearinghouse on the teaching of English.

Holden, Susan. (1981). Drama in Language Teaching. Longman:19 West 44th Street, New York,

Kao, S. M. and O' Neill, (1998). Words into Worlds: Learning a second language Through Process Drama. Stamford, London: Abbex.

Kodotchigova, M., A., (2001) Role play in Teaching culture: Six quick steps for classroom implementation. Retrieved on May 17th, 2018 from http://iteslj.org/techniques/kodotchigovaRoleplay.html

Koyluoglu, Nihal (2010). Using Drama in Teaching English for Young Learners. Selcuk University, Social Science Institute, Department of Foreign Languages Teaching English Language Teaching, Turkey.

Larsen-Freeman, D. (1990). Language Teaching Methods: Communicative Approach. Video, Retrieved on May 24th, 2018 from https://www.youtube.com/watch?v=3kRTrsKxn4

Lawson, James R.(2001). "Brain-Based Learning”. Retrieved on June $11^{\text {th }}$., 2018, from http://coe.sdsu.edu/eet/Articles/brainbased/star t.htm

Livingstone, C. (1985). Role Play in Language Learning. Harlow: Longman.

Maley, A. and Duff, A. (1982). Drama Techniques in Language Learning. Cambridge: Cambridge University Press.

Mambrol, Nasrullah (2017). Literary Theory and Criticism: Literary Criticism of John Dryden. Retrieved on June $11^{\text {th }}$., 2018, from https://literariness.org/2017/11/17/literarycriticism-of-john-dryden/

Moore, Mandie M. (2004). Using Drama as an Effective Method to Teach Elementary Students. Senior Honors Theses. 113. Eastern Michigan University. Retrieved on November $11^{\text {th }}$., 2018, from http://commons.emich.edu/honors/113

Masoumi-Moghaddam, Saman (2018). Using Drama and Drama Techniques to Teach English Conversations to English as A Foreign Language Learners. International Journal of Applied Linguistics \& English Literature. Department of English Language Literature, 
University of Tehran, Kish International Campus, Kish, Iran

Perry, Bruce (2004). "How the Brain Learns Best." Instructor Magazine. Retrieved on June $11^{\text {th }}$, 2018 , from <http://teacher.scholastic.com/professional/bru ceperry/brainlearns.htm $>$

Phillips, S. (2003). Drama with children. Oxford: Oxford University Press

Richards, Jack (1985) "Conversational competence through role play". RELC Journal 16:1

Richards, Jack C. and Theodore S. Rodgers (1986). Approaches and Methods in Language Teaching. Cambridge. Cambridge University Press

Rives, Wilga (1983) Drama in the development of oral spontaneous communication.

Shraiber, Elena and Elena Yaroslavova (2016). Drama Techniques in Teaching English as a Second Language to University Students. South Ural State University, Chelyabinsk, Russian Federation

Sofi-Karim, Mahdi (2015). English Language Teaching in the Kurdistan Region of Iraq. The School of Education of Webster University
Soleymani, Mohammad Reza and etal (2017). Comparison of the Effects of Storytelling and Creative Drama Methods on Children's Awareness about Personal Hygiene. Journal of Education and Health Promotion.

Ulas, A. H. (2008). Effects of Creative, Educational Drama Activities on Developing Oral Skills in Primary School Children. American Journal of Applied Sciences, 5. Retrieved on November $\quad 11^{\text {th }}$., 2018, from http://thescipub.com/PDF/ajassp.2008.876.880 .pdf

Via R.( 1985). Drama \& Self in Language Learning. The English Teaching Forum

Wagner, B. J. (1998). Educational Drama and Language Arts: What Research Shows. Portsmouth, N.H.: Heinemann.

Žero, A. (2014). Learning by doing: A methodological framework on teaching EFL to preschoolers. In Krawiec, M. (Ed.) Crosscurricular dimensions of language learning and teaching. Newcastle upon Tyne: Cambridge Scholars Publishing.

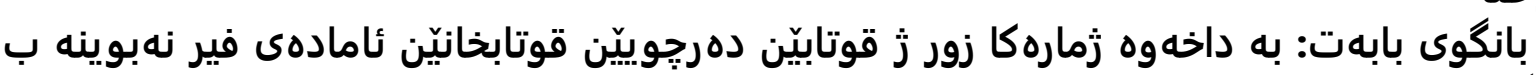

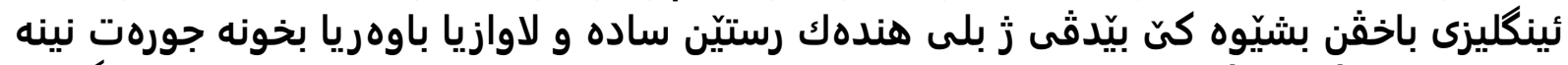

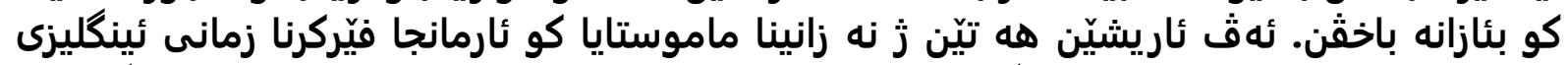

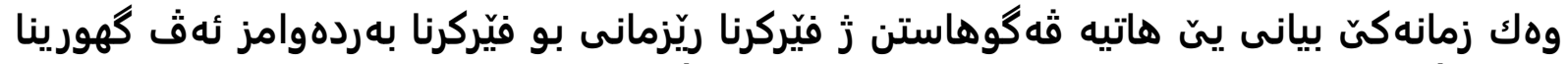

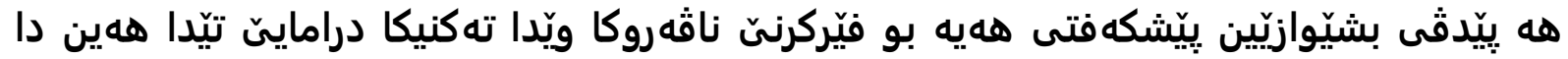

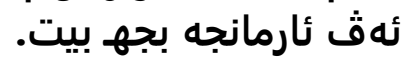

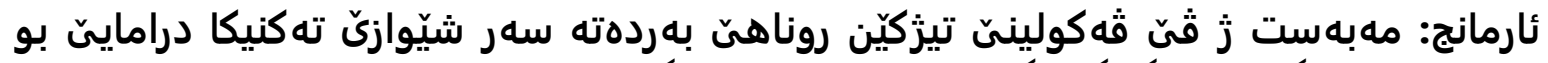

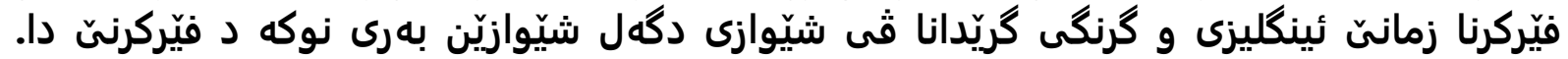

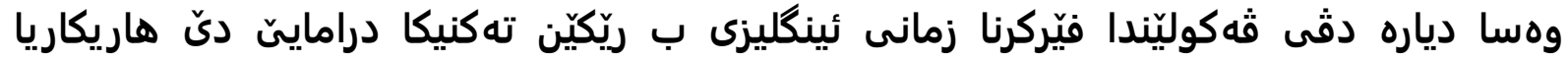

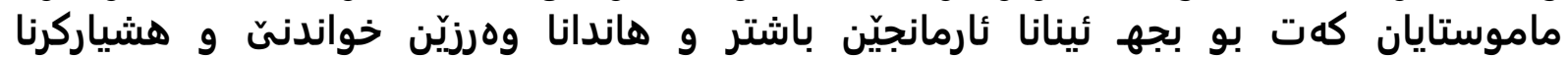

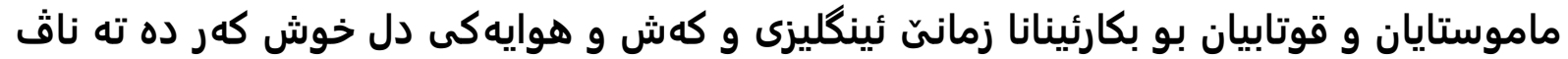

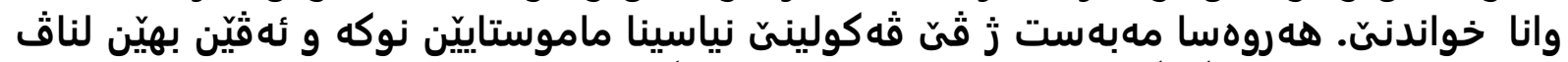

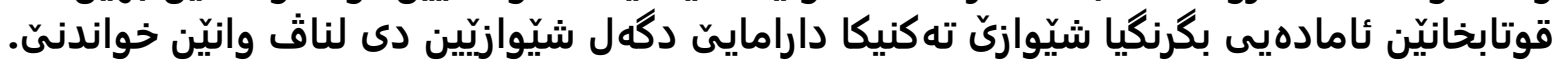

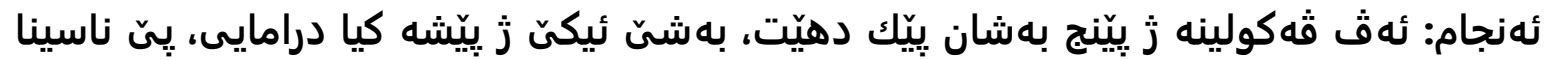

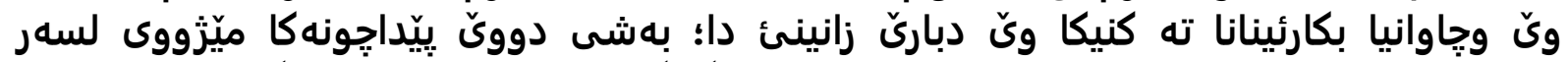

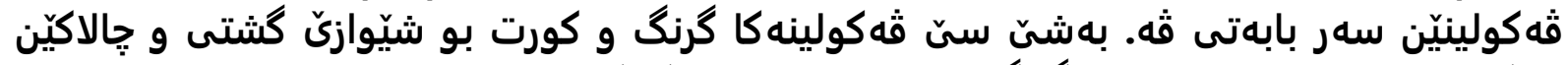

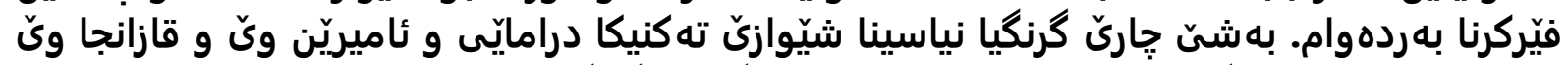

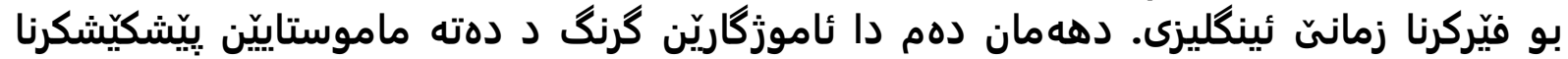

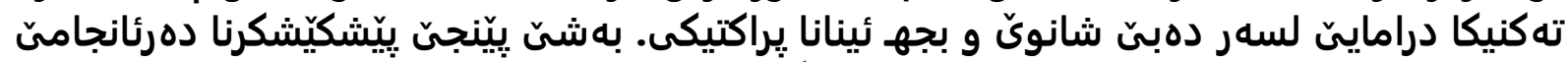

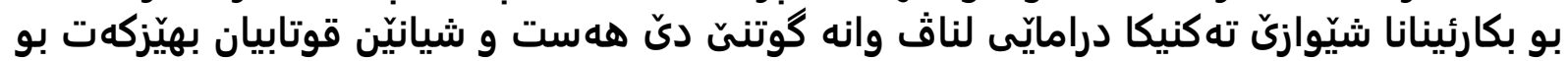

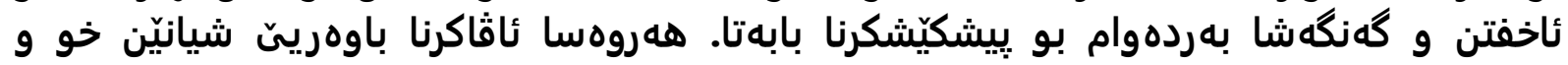




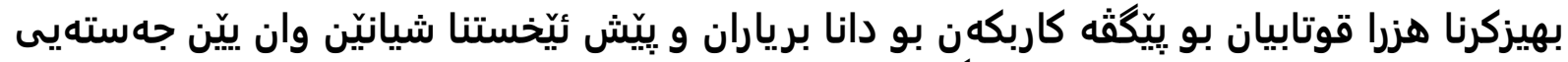

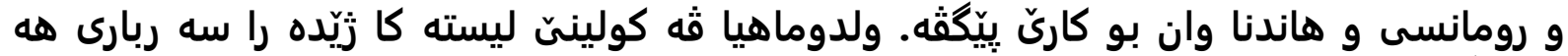
ردوو گورتييّين زمانيّ عه ره بى و كوردى.

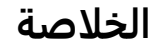

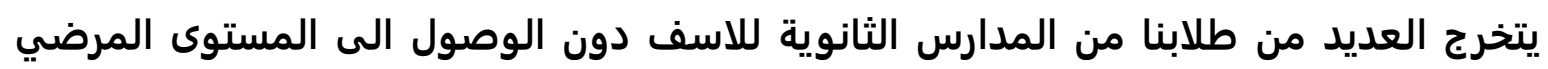

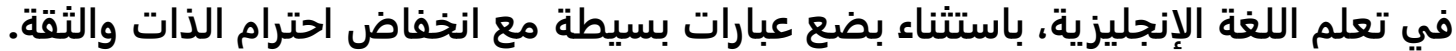

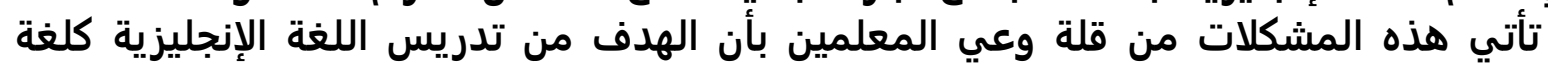

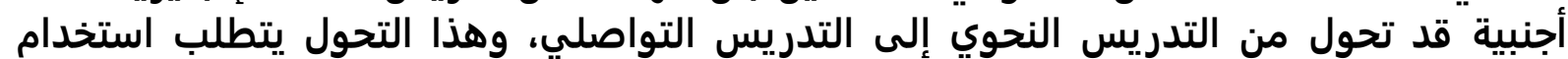

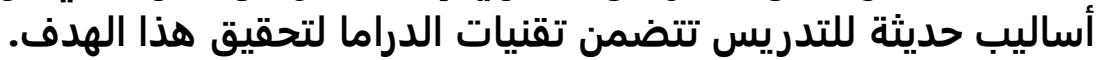

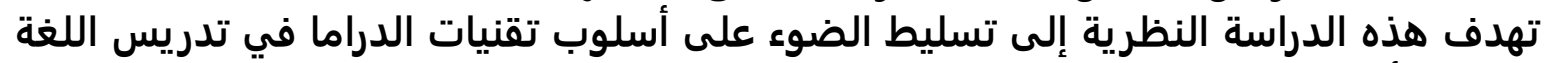
الإنجليزية وأهمية دمجها مع الأساليب التقليدية الاخرى في الإلفي التدريس.

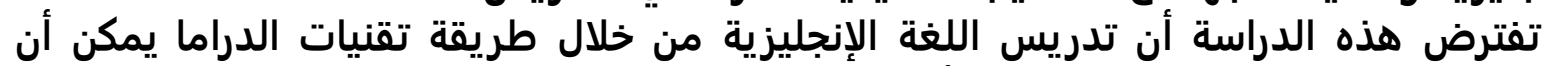

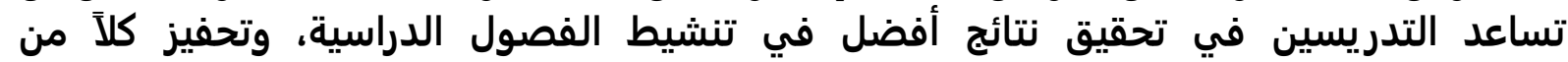

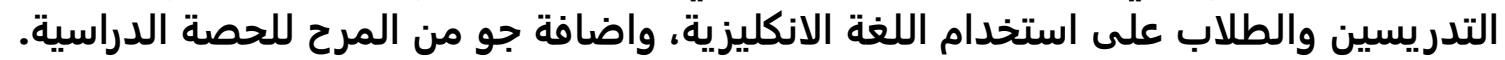

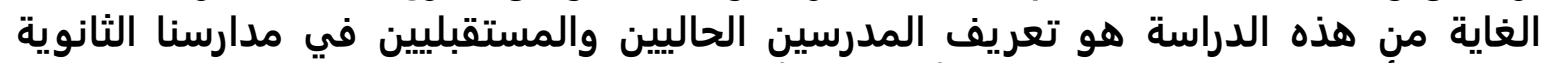

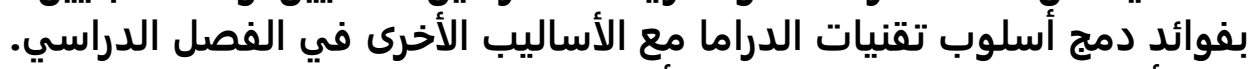

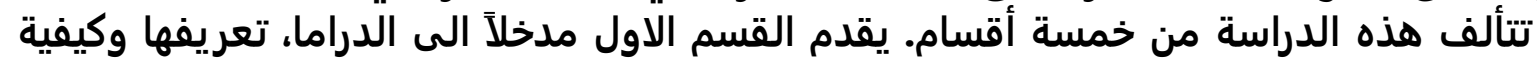

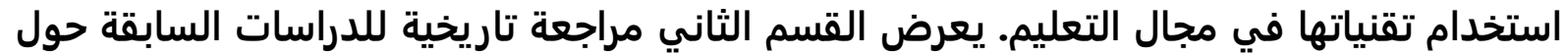

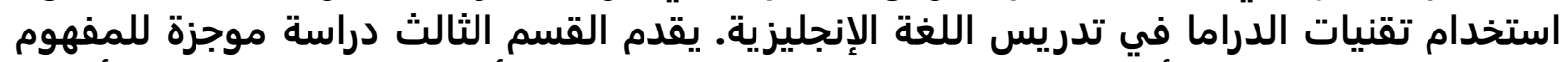

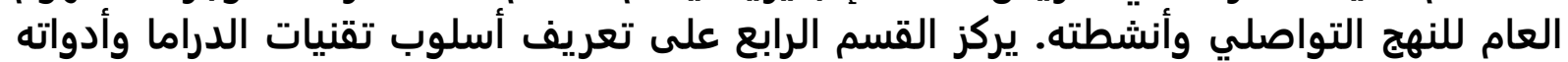

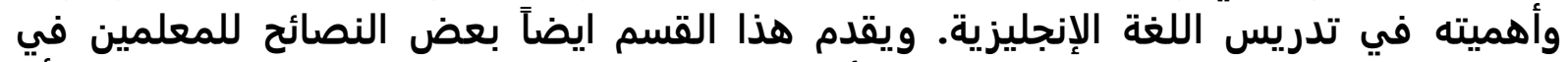

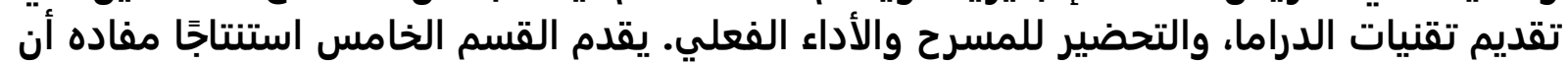

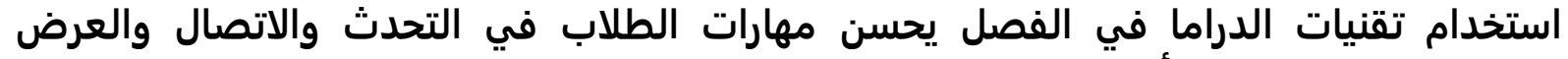

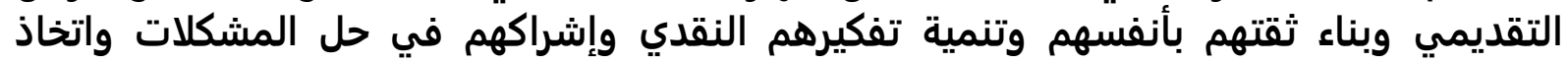

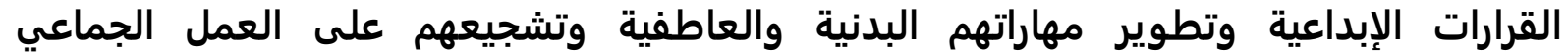

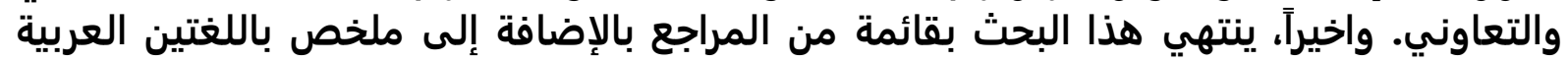
والكردية. 